\title{
Pengaruh Event Terhadap Citra Merek Majalah Femina
}

\section{The Effect of Event on Brand Image of the Femina Magazine}

\author{
Gea Wahyu Syahrinnisa ${ }^{1 *}$, Ma'mun Sarma $^{1}$ \\ 1) Departemen Manajemen, Fakultas Ekonomi dan Manajemen, IPB Kampus Dramaga Bogor 16680
}

\begin{abstract}
The print media industry dealing with large business competition due to the rise of online media. Online media provides convenience to access information. Print media utilizes online media as an information provider and a media promotion. Femina is one of the Indonesia print media merging between print and online media. Femina do marketing communication, one of them is event. This study aims to (1) identify the Femina event participants, (2) analyze the participant's perceptions regarding the conduct of Femina's event, and (3) analyze the effect of the event to the brand image of Femina Magazine. Sampling was employed by quota sampling. Respondents were 41 people which are collected when the event was performed: Healthy Action with Mama Lime and Femina, and Enchaunter L'amour Extraordinare. Data processing and analysis using Structural Equation Models (SEM) with software SmartPLS 2.0. The results showed that the majority of respondents' characteristics in accordance with Femina reader segmentation and perception of the participants' event are good. The uniqueness, atmosphere and service of the event are significant to the brand image of Femina Magazine.
\end{abstract}

Keywords: brand image, event, woman magazine, print media.

\begin{abstract}
ABSTRAK
Industri media cetak berhadapan dengan persaingan bisinis semakin berat dengan munculnya media online. Media online memberikan kemudahan mengakses informasi. Media cetak memanfaatkan media online sebagai penyedia informasi dan sebagai media promosi. Femina merupakan salah satu media cetak Indonesia yang melakukan penggabungan antara media cetak dan media online. Femina melakukan komunikasi pemasaran, salah satunya adalah event. Penelitian ini bertujuan untuk (1) Mengidentifikasi peserta event Femina, (2) Menganalisis persepsi peserta event Femina terkait pelaksanaan event, dan (3) Menganalisis pengaruh event terhadap citra merek Majalah Femina. Penarikan sampel dilakukan dengan quota sampling. Responden berjumlah 41 orang dengan event yang menjadi penelitian antara lain, Aksi Sehat Seru bersama Mama Lime dan Femina, dan Enchaunter L'amour Extraordinare. Pengolahan dan analisis data menggunakan Structural Equation Model (SEM) dengan software SmartPLS 2.0. Hasil penelitian menunjukkan bahwa mayoritas karakteristik responden sesuai dengan segmentasi pembaca Majalah Femina dan persepsi peserta event terhadap event Femina sudah baik. Keunikan dan suasana pelayanan memiliki pengaruh signifikan terhadap citra merek Majalah Femina.
\end{abstract}

Kata kunci: citra merek, event, majalah wanita, media cetak.

*Corresponding author

Alamat email: geaws12@gmail.com 


\section{PENDAHULUAN}

Industri media cetak berhadapan dengan persaingan bisnis yang berat dengan bermunculannya media online. Berbeda dengan media cetak, media online memberikan kemudahan dalam mengakses informasi dengan cepat, dan biaya yang lebih murah. Kelebihan media online menyadarkan perusahaan media cetak untuk melakukan strategi pemasaran dengan memanfaatkan media online (Sholahuddin, 2013). Banyak perusahaan media cetak melakukan penggabungan antara media cetak dengan media online salah satunya adalah majalah. Majalah tidak hanya menerbitkan majalah dalam bentuk cetak tetapi juga dalam bentuk digital. Selain mengadaptasi media online, perusahaan majalah juga melakukan berbagai strategi pemasaran agar mampu bertahan di tengah persaingan yang ketat antar media cetak dengan media online.

Femina merupakan salah satu pelopor majalah wanita di Indonesia. Femina memposisikan mereknya sebagai majalah wanita modern Indonesia. Segmentasi demografi pembaca Femina adalah wanita berusia 25 - 35 tahun, berprofesi sebagai wanita karir maupun pengusaha, berada pada status ekonomi sosial pada golongan AB (menengah ke atas) dengan pendidikan minimal S1 dan berstatus menikah. Berdasarkan segmentasi psikografi, pembaca Femina merupakan wanita yang memiliki mobilitas tinggi, mengikuti tren yang sedang berkembang. Selain itu, pembaca Femina rutin melakukan perawatan tubuh maupun kecantikan sesuai dengan statement yang dimilikinya yaitu “Gaya Hidup Masa Kini” (Rukmi, 2003).

Femina telah melakukan penggabungan antara media cetak dan media online. Media online dimanfaatkan sebagai penyedia informasi dan sebagai media promosi Majalah Femina. Femina juga melakukan komunikasi pemasaran dalam memasarkan produknya. Menurut Kotler dan Keller (2009), komunikasi pemasaran terdiri dari delapan bauran yaitu periklanan (advertising), promosi penjualan (sales promotion), penjualan langsung (direct marketing), penjualan perseorangan (personal selling), pemasaran acara atau sponsor (event sponsorship marketing), publisitas (publicity), dan pemasaran interaktif (interactive marketing). Salah satu komunikasi pemasaran yang rutin dilakukan oleh Femina adalah event. Event dapat digunakan sebagai alat untuk mencapai tujuan perusahaan, khususnya dalam meningkatkan kesadaran merek (brand awareness), memperkuat citra merek (brand image), serta untuk meningkatkan volume penjualan (Shimp, 2003).

Pelaksanaan berbagai event Femina diharapkan mampu untuk mendekatkan Femina dengan para permbacanya. Event juga diharapkan dapat mempertahankan citra merek Majalah Femina. Menurut Kotler dan Keller (2009), citra merek merupakan gambaran yang muncul dalam benak seseorang di mana orang tersebut mengingat sebuah produk tertentu. Oleh karena itu, Femina melakukan event sebagai salah satu upaya untuk mempertahankan citra merek yang dimilikinya. Maka peneliti melakukan penelitian yang berjudul "ANALISIS PENGARUH EVENT TERHADAP CITRA MEREK MAJALAH FEMINA". Tujuan pada penilitian ini 1) Mengidentifikasi karakteristik peserta event Femina 2) Menganalisis persepsi peserta event terkait pelaksanaan event Femina 3) Menganalisis pengaruh event terhadap citra merek Majalah Femina.

\section{METODE PENELITIAN}

Penelitian ini mencakup tentang bagaimana pengaruh event terhadap citra merek Femina. Penelitian ini didasari oleh 5 faktor yang merupakan karakteristik event, yaitu keunikan, perishability, intangibility, suasana dan pelayanan, serta interaksi personal. Kerangka pemikiran diuraikan pada Gambar 1. 


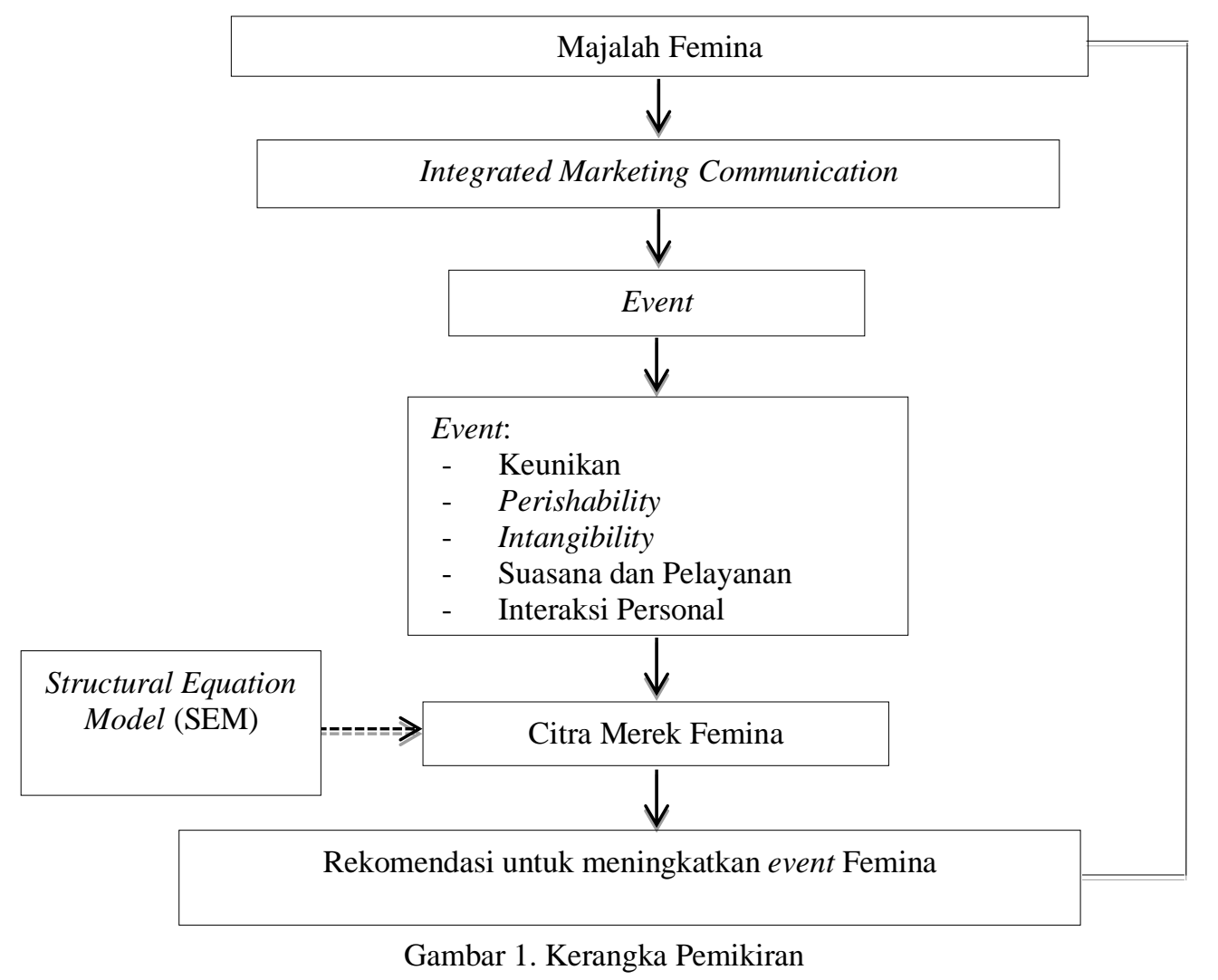

Penelitian dilaksanakan terkait pelaksanaan event Femina yaitu Aksi Sehat Seru bersama Mama Lime dan Femina dan Enchaunter L'amour Extraordinare. Pengambilan data menggunakan metode quota sampling. Jumlah sampel yang digunakan adalah peserta event. Berdasarkan hasil wawancara dengan pihak Femina, peserta event Aksi Sehat Seru bersama Mama Lime dan Femina berjumlah 12 orang. Sedangkan peserta event Enchaunter L'amour Extraordinare berjumlah 34 orang sehingga total 46 orang. Perhitungan sampel menggunakan rumus slovin, tingkat kritis sebesar 5 persen, perhitungannya sebagai berikut:

$$
n=\frac{46}{\left(1+46(0.05)^{2}\right)}=41.25=41(\text { Pembulatan })
$$

Kemudian metode pengambilan sampel dengan menggunakan teknik non probability sampling dengan quota sampling. Pembagian jumlah responden dapat dilihat pada Tabel 1.

Tabel 1. Persentase jumlah responden

\begin{tabular}{lccc}
\multicolumn{1}{c}{ Event } & $\begin{array}{c}\text { Jumlah populasi } \\
\text { (orang) }\end{array}$ & $\begin{array}{c}\text { Proposi sampel } \\
(\%)\end{array}$ & $\begin{array}{c}\text { Sampel } \\
\text { (orang) }\end{array}$ \\
\hline $\begin{array}{l}\text { Aksi Sehat Seru Bersama Mama } \\
\text { Lime dan Femina }\end{array}$ & 12 orang & 26,09 & 11 \\
$\begin{array}{l}\text { Enchaunter L'amour } \\
\text { Extraordinare }\end{array}$ & 34 orang & 73,91 & 30 \\
\hline Total & 46 & 100 & 41 \\
\hline
\end{tabular}

Sumber: Data primer diolah (2017)

Analisis data dilakukan menggunakan analisis deskriptif dengan skala likert berskala 1-5, digunakan untuk mengidentifikasi karakteristik dan persepsi responden terhadap event Femina. Selanjutnya dilakukan analisis menggunakan menggunakan alat analisis Structural Equation Model (SEM) dengan menggunakan software SmartPLS 2.0 for windows. Menurut Ghozali dan Latan (2015) SEM merupakan suatu teknik statistik yang menganalisis hubungan antar variabel yang bersifat multiple relationship. SEM mampu menganalisis pola hubungan antara variabel 
laten dan indikatornya, variabel laten satu dengan yang lainnya, serta kesalahan pengukuran secara langsung. Analisis SEM terdiri dari dua sub model yaitu validasi model pengukuran (outer model) dan pengujian model struktural (inner model).

Hipotesis adalah jawaban sementara yang menyatakan adanya pengaruh antara variabelvariabel penelitian. Hipotesis pada penelitian ini dapat dilihat pada Gambar 2.

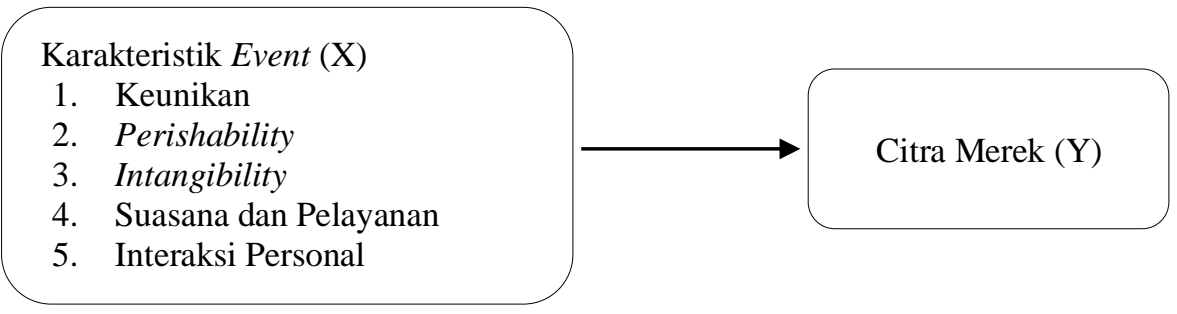

Gambar 2. Hipotesis penelitian

\section{PEMBAHASAN}

\section{Gambaran Umum Perusahaan}

Femina merupakan salah satu majalah Indonesia yang tergabung dalam Femina Group, didirikan pada awal tahun 1970an. Majalah Femina memposisikan dirinya sebagai majalah wanita modern Indonesia. Pembaca Femina merupakan wanita berusia 25 - 35 tahun dengan status lajang atau menikah. Pembaca Femina berprofesi sebagai pekerja atau wirausaha dengan status ekonomi menengah ke atas, dengan pendidikan sarjana maupun pascasarjana. Berdasarkan segmentasi psikografi, pembaca Femina merupakan wanita yang memiliki mobilitas tinggi, memperhatikan penampilan dan mengikuti tren yang sedang berkembang, rutin melakukan perawatan tubuh, serta melakukan olahraga dan diet seimbang. Hal tersebut sesuai dengan statement Femina yaitu "Gaya Hidup Masa Kini”.

Majalah Femina terbit setiap minggu dan juga menerbitkan edisi khusus seperti edisi tahunan. Femina tidak hanya menerbitkan majalah dalam bentuk cetak tetapi juga menyediakan media interaktif online, melalui website maupun media sosial. Femina melaksanakan event pribadi atau dengan melakukan kerja sama bersama perusahaan (partnership). Event pribadi merupakan event rutin yang diadakan oleh Femina seperti Pemilihan Wajah Femina. Sedangkan event yang dilakukan bersama partnership merupakan event Femina \& Friends yang disesuaikan dengan kebutuhan sponsor.

\section{Karakteristik Responden}

Penelitian ini mayoritas responden adalah wanita berusia 26-35 tahun dan usia 16-25 tahun. Rentang usia tersebut merupakan usia yang masih aktif untuk mengikuti berbagai kegiatan salah satunya adalah event Femina. Berdasarkan pendidikan, responden memiliki pendidikan terakhir sarjana sebanyak 20 orang dan profesi responden mayoritas adalah pegawai swasta. Hasil lainnya berdasarkan pendapatan diperoleh bahwa dominasi peserta event memiliki pendapatan $\mathrm{Rp} 2.000 .000,00$ - Rp 5.000.000,00 berjumlah 14 orang. Berdasarkan sumber informasi pelaksanaan event, didominasi oleh responden yang memperoleh informasi event dari sumber publik berjumlah 21 orang. Sumber publik merupakan media sosial Femina, yaitu facebook, twitter, dan instagram. Hasil ini sesuai dengann hasil sebelumnya bahwa peserta event didominasi usia 16-35 tahun yang aktif melakukan kegiatan. Selain itu, wanita berusia 1635 juga aktif untuk mengikuti perkembangan dan informasi terbaru. Hasil lainnya berdasarkan pengalaman mengikuti event diperoleh bahwa mayoritas responden baru satu kali mengikuti event Femina.

Persepsi Responden terhadap Keunikan, Perishability, Intangibility, Suasana Pelayanan, dan Interaksi Personal Event Femina

Hasil penelitian ini menunjukkan event Femina memiliki keunikan sehingga menarik bagi para peserta event. Persepsi peserta event terhadap keunikan event dapat dilihat pada Tabel 2. 
Tabel 2. Persepsi peserta event terhadap keunikan event

\begin{tabular}{clc}
\hline No & \multicolumn{1}{c}{ Pernyataan } & Skor \\
\hline 1 & Event memiliki keunikan & 4,20 \\
2 & Event berbeda dengan event lainnya & 4,07 \\
3 & Event menarik & $\mathbf{4 , 3 4}$ \\
4 & Event memiliki tema kreatif & 4,32 \\
5 & Event memberikan informasi menarik & 4,24 \\
\hline Jumlah & & 21,27 \\
Rata- Rata & & 4,23 \\
\hline
\end{tabular}

Sumber: Data primer diolah (2017)

Persepsi peserta event terhadap keunikan event adalah sangat baik $(4,23)$. Skor tertinggi berada pada item event menarik sehingga dianggap menjadi keunikan bagi peserta event Femina. Sedangkan skor terendah berada pada item event berbeda dengan event lainnya. Hal tersebut karena event dapat berlangsung berulang kali meski pun tetap memiliki perbedaan dari event-event sebelumnya.

Perishability merupakan salah satu karakteristik event terkait dengan penggunaan fasilitas saat event diselenggarakan. Fasilitas yang dimaksud adalah fasilitas yang berkaitan dengan tempat dan waktu (Noor, 2009). Tempat dan waktu pelaksaan event dapat berbeda karena disesuaikan dengan jenis kegiatan maupun tema dari setiap event yang diadakan. Persepsi peserta event terkait dengan perishability dapat dilihat pada Tabel 3.

Tabel 3. Persepsi peserta event terhadap perishability event

\begin{tabular}{clc}
\hline No & \multicolumn{1}{c}{ Pernyataan } & Skor \\
1 & Waktu pelaksanaan event tepat sesuai tema & 4,07 \\
2 & Tempat pelaksanaan event sesuai tema & $\mathbf{4 , 2 4}$ \\
2 & Event sesuai dengan waktu pelaksanaan & 3,80 \\
3 & Event dilaksanakan sesuai tempat pelaksanaan & 4,27 \\
\hline Jumlah & & 16,39 \\
Rata- Rata & & 4,10 \\
\hline
\end{tabular}

Sumber: Data primer diolah (2017)

Berdasarkan Tabel 3, perishability event Femina adalah baik $(4,10)$. Pemilihan waktu dan tempat pelaksanaan event sudah sesuai dengan tema event. Tempat pelaksanaan event sudah sangat baik dengan skor tertinggi yaitu 4,24. Sedangkan, waktu pelaksanaan event dianggap baik.

Menurut Noor (2009) intangibility adalah sesuatu yang tidak berwujud namun mampu mengubah persepsi para peserta event. Intangibility meliputi pengalaman yang didapatkan oleh peserta setelah mengikuti event antara lain perasaan, emosi, pemikiran, perilaku, maupun pengembangan diri (Pudjiastuti, 2010). Persepsi peserta event terkait intangibility dapat dilihat pada Tabel 4.

Tabel 4. Persepsi peserta event terhadap intangibility event

\begin{tabular}{clc}
\hline No & Pernyataan & Skor \\
\hline 1 & Event memberikan kesan positif & $\mathbf{4 , 3 4}$ \\
2 & Event memberikan hiburan & 4,32 \\
3 & Event memberikan informasi & 4,32 \\
4 & Event memiliki sisi edukatif & 4,22 \\
\hline Jumlah & & 17,20 \\
Rata- Rata & & 4,30
\end{tabular}

Sumber: Data primer diolah (2017)

Persepsi peserta event terdahap intangibility sangat baik $(4,30)$. Peserta event memiliki persepsi bahwa event memberikan kesan positif, hiburan, informasi yang sangat baik dan sangat berguna bagi para peserta event. Selain itu, event juga memiliki sisi edukatif, tidak hanya sebatas menjadi hiburan tetapi juga menjadi sarana untuk memperoleh informasi bagi para peserta event. 
Suasana dan pelayanan event merupakan salah satu karakteristik yang penting saat pelaksanaan event. Menurut Noor (2009), event yang dilaksanakan dengan suasana baik akan berpengaruh terhadap kesuksesan event. Persepsi peserta event terhadap suasana dan pelayanan ketika pelaksanaan event dapat dilihat dalam Tabel 5.

Tabel 5. Persepsi peserta event terhadap suasana dan pelayanan event

\begin{tabular}{clc}
\hline No & \multicolumn{1}{c}{ Pernyataan } & Skor \\
\hline 1 & Suasana event terlaksana dengan baik & 4,07 \\
2 & Suasana event nyaman & 4,20 \\
3 & Suasana event menyenangkan & $\mathbf{4 , 2 9}$ \\
4 & Pelayanan yang diberikan memuaskan & 4,02 \\
5 & Event ditunjang dengan sarana dan prasarana memadai & 4,27 \\
\hline Jumlah & & 20,85 \\
Rata- Rata & & 4,17 \\
\hline
\end{tabular}

Sumber: Data primer diolah (2017)

Persepsi peserta event terhadap suasana dan pelayanan sudah baik. Hal tersebut dapat dilihat dari skor rata-rata sebesar 4,17. Para peserta merasa bahwa event memiliki suasana yang menyenangkan dengan skor sebesar 4,29. Selain itu, peserta juga merasa bahwa event memiliki suasana yang baik dan nyaman ditunjang dengan sarana dan prasarana yang memadai. Sedangkan skor terendah adalah pelayanan yang diberikan memuaskan $(4,02)$ namun dapat diartikan bahwa pelayanan yang diberikan oleh panitia selama pelaksanaan event sudah cukup baik.

Interaksi personal menciptakan suasana event yang lebih hidup. Selain itu, peserta event akan merasakan pengalaman sebagai bagian dari event (Noor, 2009). Persepsi peserta event terhadap interaksi personal dapat dilihat dalam Tabel 6.

Tabel 6. Persepsi peserta event terhadap interaksi personal event

\begin{tabular}{clc}
\hline No & \multicolumn{1}{c}{ Pernyataan } & Skor \\
\hline 1 & Event terlaksana dengan adanya tanya jawab interaktif & 4,02 \\
2 & Mengajak untuk berpartisipasi secara aktif & 3,93 \\
3 & Merasa terlibat secara langsung & 4,05 \\
4 & Menerima informasi dan memberi respon secara langsung & $\mathbf{4 , 1 2}$ \\
\hline Jumlah & & 16,12 \\
Rata- Rata & & 4,03 \\
\hline
\end{tabular}

Sumber: Data primer diolah (2017)

Berdasarkan Tabel 6, persepsi event terkait interaksi personal adalah baik dengan ratarata skor 4,03. Skor tertinggi $(4,12)$ menujukkan bahwa peserta event merasa menerima informasi dan dapat memberi respon secara langsung selama event diselenggarakan. Hal tersebut juga berhubungan dengan persepsi bahwa peserta event terlibat secara langsung dalam event tersebut.

\section{Analisis Pengaruh Pelaksanaan Event Terhadap Citra Merek Majalah Femina}

Alat analisis yang digunakan untuk melihat pengaruh pelaksanaan event terhadap citra merek Femina adalah Partial Least Square (PLS) yang merupakan salah satu jenis dari Structural Equational Modeling (SEM). Model pengukuran pada SEM dibagi menjadi dua yaitu model pengukuran (outer model) dan model struktural (inner model). Outer model menujukkan variabel manifest (indikator) menginterpretasikan variabel laten (konstruk) untuk diukur. Sedangkan, inner model menujukkan kekuatan estimasi antar variabel laten (konstruk). Outer model pada penelitian ini ditunjukkan pada gambar yang merupakan model awal penelitian. Outer model dilakukan untuk menilai validitas dan reliabilitas model. Penelitian ini direfleksikan oleh 35 variabel manifest (indikator) yang berasal dari enam variabel laten (konstruk) yaitu keunikan, perishability, intangibility, suasana dan pelayanan, interaksi persona, serta citra merek.

Menurut Ghozali dan Latan (2015), model pengukuran dilakukan dengan melihat nilai Organisasi (JMO), 
konvergen. Validitas diskriminan dilakukan dengan melihat nilai cross loading. Sedangkan, reabilitas dilakukan dengan melihat conbrah's alpha dan composite reliability.

Nilai loading factors indikator reflektif disyaratkan dengan nilai minimum 0,7. Average Variance Extracted (AVE) diisyaratkan dengan nilai di atas 0,5, dan communality dengan nilai di atas 0,5. Cross Loading merupakan bagian dari uji validitas diskriminan diisyaratkan dengan nilai 0,7 atau setiap indikator loading factor memiliki nilai lebih besar dari indikator laten lainnya. Sedangkan, conbrah's alpha dan composite reliability dilakukan untuk melihat reabilitas yang diisyaratkan dengan nilai 0,7. Tahap awal pada model pengukuran (outer model) adalah dengan melihat nilai loading factors setiap indikator yang merefleksikan variabel laten (konstruk). Pada penilitan ini terdapat 35 indikator yang dapat dilihat pada Gambar 3.

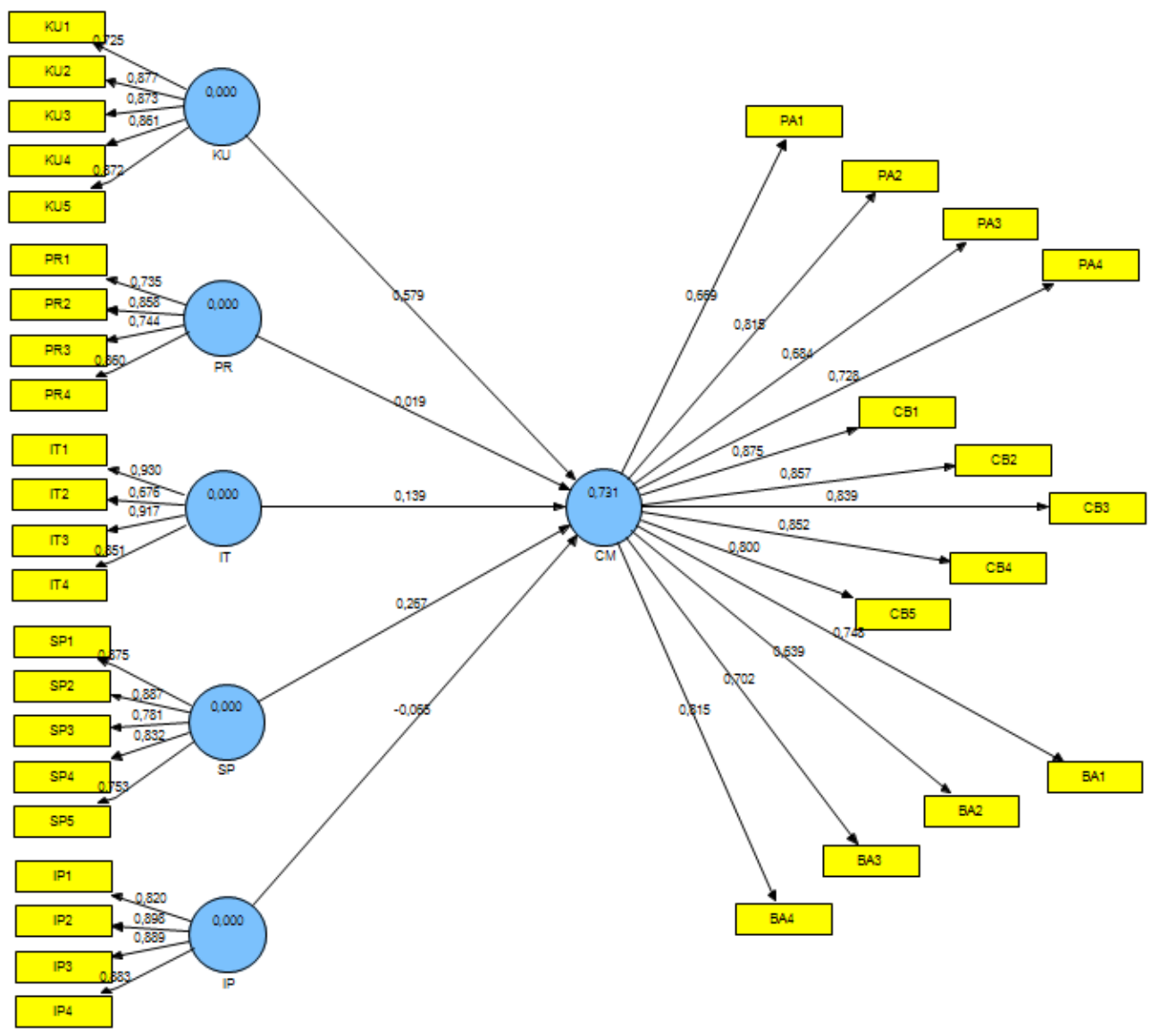

Gambar 3. Model Awal

Berdasarkan Gambar 3 terlihat bahwa dari 35 indikator yang ada, terdapat empat indikator yang memiliki nilai loading factors di bawah 0,7 yaitu IT2, PA1, PA3, dan BA. Indikator tersebut harus dibuang atau dihapus dari model. Proses ini disebut dengan proses dropping. Proses dropping dilakukan dengan membuang satu persatu indikator yang memiliki nilai loading factors di bawah 0,7 kemudian diolah kembali. Jika masih terdapat indikator yang memiliki nilai loading factors di bawah 0,7 proses dropping dilakukan berulang hingga semua indikator memiliki nilai loading factors di atas 0,7. Pada model ini terdapat indikator yang dibuang pada saat proses dropping kedua yaitu BA3. Setelah proses dropping selesai dilakukan maka tersisa 30 indikator yang ditunjukkan pada model akhir. Hasil ini menunjukkan indikatorindikator yang mempengaruhi citra merek majalah Femina dapat dilihat pada Gambar 4. 


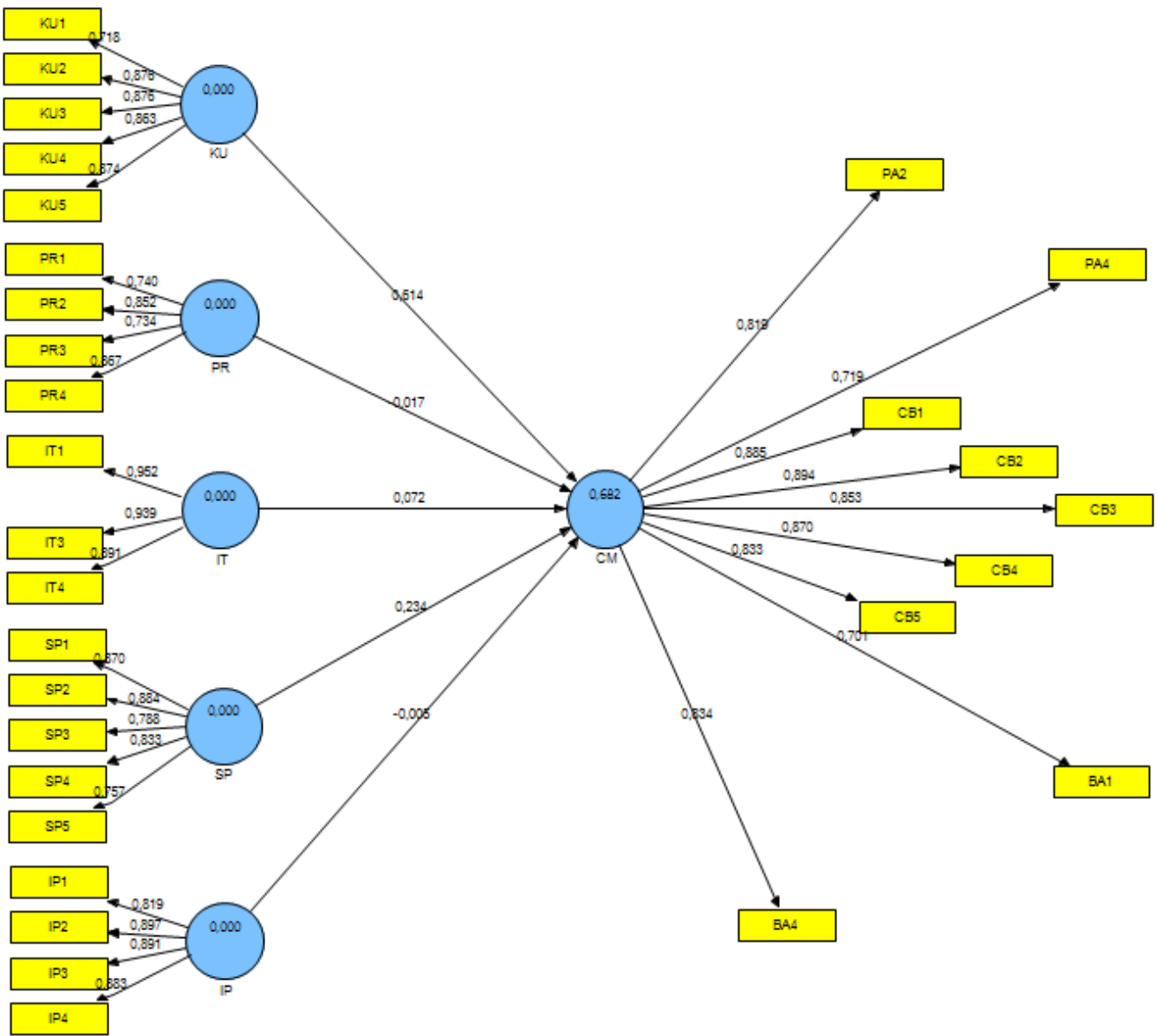

Gambar 4. Model Akhir

Berdasarkan Gambar 4, setelah melalui proses dropping terlihat beberapa indikator yang hilang. Konstruk keunikan (KU), semua indikator dapat merefleksikan dengan dengan baik. Hasil ini menyatakan bahwa event memiliki keunikan, berbeda dengan event lainnya, menarik, memiliki tema kreatif, dan memberikan informasi menarik. Menurut Hoyle (2002), event dapat memberikan kesan baik dengan memiliki tiga hal yaitu entertainment, excitement, dan enterprise. Entertainment adalah bagaimana event memberikan manfaat bagi para peserta dengan memberikan hiburan. Excitement adalah bagaimana event membuat pserta event merasa puas dan memberikan kesan positif. Sedangkan, enterprise adalah bagaimana event diciptakan secara inovatif, kreatif, dan atraktif bagi para peserta event. Hal ini menunjukkan bahwa event Femina sudah memberikan kesan yang baik karena menarik dan kreatif sehingga menjadi daya tarik bagi peserta event.

Konstruk perishability (PR) direfleksikan oleh empat indikator PR1, PR2, PR3, dan PR4. Keempat indikator ini menunjukkan bahwa pelaksanaan femina sudah sesuai antara waktu dan tempat pelaksanaan dengan tema event. Konstruk intangibility (IT) indikator yang tersisa direfleksikan oleh indikator IT1, IT3, dan IT4. IT1 adalah peserta event merasa bahwa event memberikan kesan positif. IT3 adalah event memberikan informasi, dan IT4 adalah event memiliki sisi edukatif. Event Femina sudah memberikan pengalaman berdasarkan perasaan yaitu kesan positif, emosi yaitu menghibur, dan pemikiran dengan memberikan informasi event yang memiliki sisi edukatif. Konstruk suasana dan pelayanan (SP) direfleksikan oleh indikator SP1, SP2, SP3, SP4, dan SP5. Kelima indikator tersebut menunjukkan bahwa event Femina memiliki suasana yang baik, nyaman, dan menyenangkan bagi para peserta event. Panitia event memberikan pelayanan yang memuaskan, serta pelaksanaan event ditunjang dengan sarana dan prasarana yang memadai. Konstruk interaksi personal, indikator yang merefleksikannya adalah IP1, IP2, IP3, dan IP4. Keempat indikator tersebut menujukkan bahwa event berlangsung secara 
atraktif dan interaktif. Peserta event merasa berpartisipasi secara langsung dan juga dapat memberikan respon secara langsung.

Variabel laten citra merek (CM), direfleksikan oleh indikator PA2, PA4, CB1 - CB5, dan BA1 serta BA4. Indikator PA menujukkan bahwa melalui event para peserta lebih memahami product attributes terkait rubrik dan gambar/foto majalah Femina. Indikator consumer benefits menunjukkan bahwa melalui event peserta lebih memahami bahwa konten majalah Femina bersifat informatif, edukatif, dan menghibur. Selain itu, peserta event juga lebih memahami bahwa majalah Femina sangat baik untuk dibaca. Hal tersebut menujukkan bahwa majalah Femina memiliki fungsi sebagai media cetakmdiantaranya, menginformasikan, mendidik, meghibur, dan mempengaruhi (Effendy, 2007). Indikator BA1 dan BA4 menujukkan bahwa melalui event peserta semakin yakin Femina merupakan majalah wanita Indonesia dan wanita Indonesia perlu membaca majalah Femina.

Menurut Ghozali dan Latan (2015), selain melihat loading factors validitas komvergen perlu dievaluasi dengan melihat nilai Average Variance Extracted (AVE), dan communality. Validitas disrkiminan dengan melihat nilai cross loading. Sedangkan, reliabilitas dengan melihat nilai cronbach's alpha dan composite reliability. Evaluasi tersebut dilakukan agar model penelitian dikatakan valid dan reliabel.

Evaluasi model struktural (inner model) dilakukan dengan melihat nilai $R$-square yang merupakan uji goodness-fit model. Karakteristik event memiliki pengaruh terhadap citra merek majalah Femina ditandai dengan nilai $R$-square sebesar 0,682. Nilai tersebut menujukkan bahwa konstruk citra merek majalah Femina dapat dijelaskan oleh variabilitas karakeristik event sebesar $68,2 \%$ dan termasuk kategori kuat. Sedangkan sisanya $(31,2 \%)$ diinterpretasikan bahwa konstruk citra merek majalah Femina dijelaskan oleh variabel lain di luar variabel yang diteliti.

Tahapan selanjutnya adalah melihat nilai t-statistik sebagai acuan signifikasi statistik model dengan menguji hipotesis untuk setiap jalur hubungan. Hasil ini diperoleh setelah melakukan bootstrapping pada model. Kriteria variabel yang memiliki pengaruh signifikan yaitu t-statistik variabel bernilai lebih besar dari 1,96 (dengan alpha 5\%). Berdasarkan hasil evaluasi, maka diperoleh dua dari lima variabel yang memiliki pengaruh signikan terhadap citra merek yaitu keunikan dan suasana pelayanan event, dapat dilihat pada Gambar 5. 


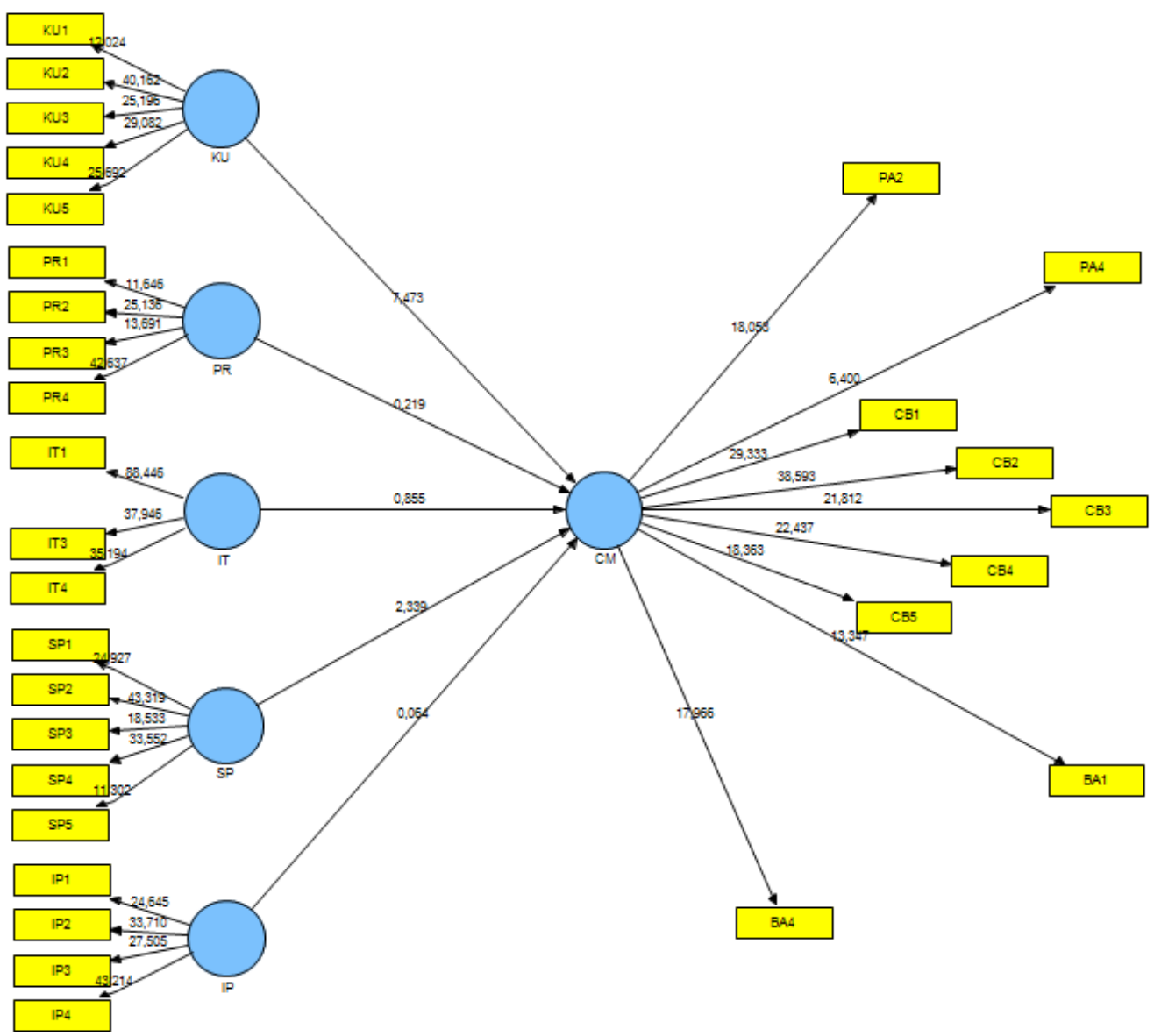

Gambar 5. Bootstrapping

Variabel keunikan memiliki pengaruh positif terhadap citra merek majalah Femina dengan nilai t-statistik sebesar 7,473 dan nilai koefisiennya sebesar 0,614 . Sehingga dapat diinterpretasikan bahwa setiap peningkatan faktor keunikan event sebesar $1 \%$ maka akan meningkatkan citra merek majalah Femina sebesar $61,4 \%$. Berdasarkan uraian tersebut, maka $\mathrm{H}_{1.0}$ ditolak atau terdapat pengaruh signifikan antara keunikan event terhadap citra merek Majalah Femina. Variabel lain yang juga memiliki pengaruh positif signifikan adalah suasana dan pelayanan dengan nilai t-statistik sebesar 2,339 dan nilai koefisiennya adalah 0,234. Sehingga dapat diartikan bahwa setiap kenaikan $1 \%$ suasana dan pelayanan event maka akan meningkatkan citra merek majalah Femina sebesar 23,4\%. Hal tersebut menunjukkan bahwa $\mathrm{H}_{4.0}$ ditolak karena terdapat pengaruh signifikan antara suasana dan pelayanan event terhadap citra merek Majalah Femina. Variabel-variabel lain seperti perishability, intangibility, dan interaksi personal tidak memiliki pengaruh positif signifikan terhadap citra merek majalah Femina.

\section{Implikasi Manajerial}

Implikasi manajerial diberikan berdasarkan hasil yang didapat dari penelitian ini. Segmentasi peserta event Femina pada rentang usia 16-35 tahun, wanita masa kini yang aktif beraktivitas dan sesuai dengan segmentasi pembaca majalah Femina. Hasil selanjutnya menunjukkan bahwa event Femina sudah baik namun perlu dilakukan peningkatan. Peningkatan event dapat dilakukan berdasarkan karakteristiknya. Peningkatan event terkait keunikan dilakukan dengan membuat tema yang mengukuti perkembangan terkait gaya hidup, hobi, maupun mengangkat permasalahan wanita. Kegiatan yang dilakukan lebih beragam seperti jalan-jalan, kunjungan pabrik, maupun acara untuk keluarga. Perishability event dapat dilakukan dengan tempat dan waktu sesuai tema serta pelasakanaan tepat waktu. 
Peningkatan intangibility event dapat dilakukan dengan materi pembicara lebih baik dan menarik. Peningkatan suasana dan pelayanan event dapat dilakukan dengan sarana prasarana yang memadai dan jumlah peserta yang sesuai agar suasana event nyaman dan menyenangkan. Peningkatan interaksi personal dapat ditingkatkan dengan menampilkan pembicara ahli menarik dan sesuai tema. Interaksi personal menciptakan suasana event yang lebih hidup. Peserta event akan merasakan pengalaman sebagai bagian dari event (Noor, 2009). Selain itu, dapat dilakukan live report melalui media sosial sehingga pembaca Femina yang tidak hadir mengetahui dan mengikuti event yang dilaksanakan.

Event mampu memberikan pengaruh postif terhadap citra merek Femina, tidak hanya terkait consumer bennefits, tetapi juga terkait produk attribut dan brand attitudes. Event harus mampu menggambarkan citra majalah Femina terkait produk maupun merek. Kegiatan dapat dilakukan dengan mengadakan kunjungan ke redaksi Femina, mengadakan workshop terkait atribut Femina, atau menampilkan pembicara dan bintang tamu yang merupakan bagian dari Femina. Pelaksanaan event dapat berpengaruh terhadap citra merek Femina dalam benak peserta event tetapi juga masyarakat secara luas, sehingga perlu diadakan event yang lebih besar dan publikasi yang juga lebih luas.

\section{KESIMPULAN}

Berdasarkan hasil penelitian yang telah dilakukan, maka diperoleh simpulan bahwa karakteristik responden mayoritas terdiri dari wanita berusia 26 - 35 tahun, berdomisili di Jakarta, berprofesi sebagai pegawai swasta dengan pendidikan terakhir sarjana dan memiliki pendapatan menengah ke atas. Mayoritas responden mengikuti event Femina sebanyak satu kali dan memperoleh informasi tentang pelaksanaan event dari sumber publik (media sosial). Seluruh variabel bebas yeng terdiri dari keunikan, perishability, intangibility, suasana dan pelayanan, serta interaksi personal memperoleh persepsi baik dari responden. Variabel keunikan dan suasana pelayanan event memiliki pengaruh positif signifikan terhadap citra merek majalah Femina. Keunikan merupakan variabel yang paling besar pengaruhnya terhadap citra merek majalah Femina dengan nilai koefisien 0,614.

\section{DAFTAR PUSTAKA}

Effendy, O. U. (2007). Ilmu Komunikasi: Teori dan Praktek. Bandung: Remaja Rosdakarya.

Ghozali, I., \& Latan, H. (2015). Partial Least Square: Konsep, Teknik dan Aplikasi Menggunakan Program SmartPLS 3.0. Semarang: Universitas Dipenogoro.

Hoyle, L. H. (2002). Event Marketing: How to Successfully Promote Events, Festivals, Conventions, and Expositions. New York: John Wiley \& Sons, Inc.

Kotler, P., \& Keller, K. L. (2009). Manajemen Pemasaran Jilid 1 Edisi 13. Jakarta: Erlangga.

Noor, A. (2009). Manajemen Event. Bandung: Alfabeta.

Pudjiastuti, W. (2010). Special Event Alternatif Jitu Membidik Pasar. Jakarta: Elex Media Komputindo.

Rukmi, M. (2003). Analisa Hubungan Strategi Komunikasi Pemasaran dengan Loyalitas Merek pada Majalah Wanita (Studi Kasus Majalah Femina) [tesis]. Jakarta: Universitas Indonesia.

Shimp, T. A. (2003). Periklanan Promosi dan Aspek Tambahan Komunikasi Pemasaran Terpadu. Jakarta: Erlangga.

Sholahuddin. (2013). Strategi Pengembangan Produk di Industri Media Cetak di Indonesia (Bertahan di Tengah Persaingan dengan Media Online). Benefit Jurnal Manajemen dan Bisnis, 17(1). 